\title{
КОМПЛЕКСНА ОЦІНКА ФУНКЦІОНАЛЬНИХ ЗМІН В ОРГАНІЗМІ ЗДОРОВИХ ЩУРІВ, ЩО СПОЖИВАЛИ В ЯКОСТІ ПИТНО ВОДУ ОЗ. КАТЛАБУХ
}

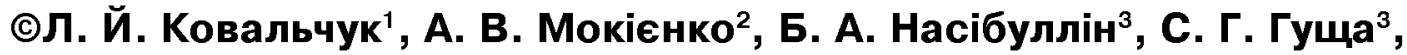 \\ О. Я. Олешко ${ }^{3}$, О. І. Бахолдіна ${ }^{3}$ \\ Одеський національний медичний університет ${ }^{\prime}$ \\ Державне підприємство Український науково-дослідний інститут медицини транспорту \\ Міністерства охорони здоров'я України ${ }^{2}$ \\ Державна установа "Український науково-дослідний інститут медичної реабілітації та курортології \\ Міністерства охорони здоров'я України»з3
}

\begin{abstract}
РЕЗЮМЕ. Робота присвячена комплексній оцінці функціональних змін в організмі здорових щурів, що споживали в якості питно воду оз. Катлабух. Результати фізико-хімічних та санітарно-хімічних досліджень свідчать про відповідність вимогам ДСТУ 4808:2007 до джерел 2-4 класу якості. У воді оз. Катлабух виявлено 2 види ціанобактерій Merismopedia minima та Spirulina laxissima, які викликають «цвітіння» води. Встановлено, що вживання здоровими щурами як питно води оз. Катлабух супроводжується наступними ефектами: підвищенням активності ЦНС; компенсаторною функціональною гіпоксією; зростанням вмісту гетерогенних антитіл і появою достатньо кількості антитіл до печінки, тобто аутоімуних реакцій; зниженням рН сечі, затримці іонів натрію і калію. Зважаючи на відсутність гігієнічно значимих концентрацій антропогенних забруднювачів, висловлено думку, що виявлені біологічні ефекти $\epsilon$ наслідком ді ціанотоксинів або токсичних органомінеральних комплексів. Обгрунтована доцільність розширення та продовження досліджень ціанобактерій у контекстах х виявлення у воді, ідентифікаці ціанотоксинів, впливу цих ксенобіотиків на стан теплокровних тварин та людини.

КЛЮЧОВІ СЛОВА: вода, озеро Катлабух, хімічний склад, антропогенні забруднювачі, ціанобактері , біологічні ефекти, щури.
\end{abstract}

Вступ. Однією із гострих проблем сучасно екологі та водокористування є розмноження у різноманітних поверхневих водоймах синьозелених водоростей (ціанобактерій). Характерною ознакою цих мікроорганізмів $\epsilon$ не інфективність для організму теплокровних і людини, а здатність продукувати небезпечні для здоров'я специфічні токсини (ціанотоксини), які проявляють тропність до певних органів та систем (гепатотоксини, нейротоксини, дерматотоксини тощо) [1, 2]. Останніми роками цю проблему пов'язують із «цвітінням» водойм, яке розглядають як ключовий чинник замору риби та інших гідробіонтів, а також можливого ускладнення санітарно-епідеміологічно ситуаці внаслідок передумов розмноження збудників кишкових інфекцій $[3,4]$. Ціанобактері та ціанотоксини інтисивно досліджуються у багатьох кра нах, однак в Украні інформаці у цьому контексті вкрай мало. Особливо це стосується впливу ціанотоксинів на організм теплокровних у сенсі моделювання патологічних змін у людини. Тому мета дано роботи полягала у комплексній оцінці функціональних змін в організмі здорових щурів, що споживали в якості питно воду оз. Катлабух, яке влітку потерпає від надмірного «цвітіння».

Матеріали і методи дослідження. Зразки води оз. Катлабух у 3-х повторностях відбирали 23, 24 липня 2014 р. Перед проведенням досліджень води на лабораторних тваринах виконано фізико-хімічні та санітарно-хімічні дослідження за відповідними методиками [5].
Ідентифікацію ціанобактерій (альгологічні дослідження) проводили шляхом прямо мікроскопі краплі води за відповідною методикою [6].

Статистичну обробку результатів фізико-хімічних, санітарно-хімічних та альгологічних досліджень проводили параметричними методами 3 використанням програмного забезпечення Excel 2010 (Microsoft Inc., США).

Експериментальні дослідження проведено на 30 білих щурах-самицях ліні Вістар аутбредного розведення з масою тіла 150-200 г. Під час всього періоду досліду тварини перебували на постійному стандартному харчовому та питному режимі в умовах утримання у віварі ДУ «Укр НДІ МР та К МОЗ Укра ни». Тварин виводили із експерименту шляхом декапітаці під ефірним наркозом. Дослідження над тваринами проводили згідно з існуючими правовими документами [7, 8].

Експериментальні дані порівнювали з подібними показниками інтактних щурів (контрольна група). Щурів було поділено на 2 групи. Перша контрольна група порівняння (12 інтактних тварин). Тварини друго (дослідно ) групи (18 тварин) вживали воду оз. Катлабух у режимі ad libera (вільного доступу). Тривалість експерименту склала 30 діб.

Досліджували наступні параметри: функціональний стан центрально та вегетативно нервово системи у приладі «відкрите поле», функціональну активність ЦНС (тіопенталова проба), стан імунітету (циркулюючі імунні комплекси (ЦІК), 
Оеляди літератури, оригінальні дослідження, поеляд на проблему

гетерогенні антитіла (ГА), антитіла печінки, антитіла мозку) і показників периферійно крові, стан функціонально активності нирок.

Методики фізіологічних та імунологічних досліджень викладено у відповідному документі [9].

Отриманий матеріал обробляли статистичними методами непрямих різниць. Вірогідними змінами вважали ті, що знаходились, за таблицями Стьюдента, у межах вірогідності <0,05 [10].

Результати й обговорення. Результати фізико-хімічних досліджень, які оцінювали на відповідність вимогам чинних нормативних документів ДСТУ 4808:2007 [11] та СанПіН № 4630-88 [12], свідчать, що вода оз. Катлабух за основними фізико-хімічними показниками не відповідала вимогам СанПіН № 4630-88 [12] за вмістом натрію + калію, хлоридіонів, сульфат-іонів та сухим залишком. За більш жорстким нормативом ДСТУ 4808:2007 ці показники, а також жорсткість та магній, відповідають вимогам до джерел 4 класу; до 2 класу за каламутністю, окиснюваністю, лужністю); до 3 - за лужністю та водневим показником. За санітарно-хімічними показниками (азот амонійний, азот нітритний, нафтопродукти, феноли) вода оз. Катлабух відноситься до джерел 2, за загальним органічним вуглецем - до 4 класу якості [11].

У зразках води оз. Катлабух вміст хлорорганічних пестицидів (ХОП) знаходився за межею чутливості прилада, а саме (мг/дм²): ліндан <0,00016; гептахлор<0,00023; ДДЕ<0,00049; ДДД<0,00069; ДДТ<0,00107.

Що стосується важких металів (Cd, Pb, Mn, Cr, $\mathrm{Zn}, \mathrm{Cu}, \mathrm{V})$, то у зразках води вміст V відповідав джерелам 4 класу [11].

У воді оз. Катлабух виявлено високі рівні Merismopedia minima та Spirulina laxissima (у середньому 3360000 та 3990000 клітин/дм³), які $\epsilon$ ознаками «цвітіння» води.

Результати експериментальних досліджень на лабораторних тваринах показують наступне.

Оцінку функціонально активності ЦНС і ВНС щурів, що одержували воду оз. Катлабух, здійснювали методом «відкритого поля». Результати досліджень представлено у таблиці 1.

Таблиця 1. Вплив води оз. Катлабух на функціональний стан ЦНС та ВНС здорових щурів

\begin{tabular}{|l|c|c|c|}
\multicolumn{1}{|c|}{ Показники } & $\begin{array}{c}\text { Контрольна група } \\
\left(\mathrm{M}_{1} \pm \mathrm{m}_{1}\right)\end{array}$ & $\begin{array}{c}\text { Дослідна група } \\
\left(\mathrm{M}_{2} \pm \mathrm{m}_{2}\right)\end{array}$ & $\mathrm{p}$ \\
\hline Рухова активність, $\mathrm{n}$ & $2,33 \pm 0,41$ & $3,47 \pm 0,04$ & $<0,02$ \\
\hline Орієнтувально-дослідницька поведінка, $\mathrm{n}$ & $34,53 \pm 2,51$ & $45,02 \pm 1,07$ & $<0,02$ \\
\hline Зміщена активність, $\mathrm{n}$ & $4,93 \pm 0,83$ & $5,37 \pm 0,07$ & $>0,5$ \\
\hline Емоційна активність, $\mathbf{n}$ & $8,47 \pm 1,13$ & $8,54 \pm 0,13$ & $>0,5$ \\
\hline
\end{tabular}

Як свідчать результати дослідження, щури, що одержували воду оз. Катлабух, демонстрували достовірне збільшення кількості перетнутих квадратів і кількості виходів у центр клітини. Такожзбільшувалась кількість вертикальних стійок і кількість заглядань у нірки. У цілому можна говорити про підвищення рухово і орієнтовно-дослідницько активності щурів, а це у свою чергу свідчить про підвищену функціональну активність ЦНС. 3 боку ВНС підвищення активності не спостерігалося, про що свідчило збереження на рівні контролю кількості завмирань, кількості і тривалості грумінгів, кількостіболюсів.
Підвищення функціонально активності ЦНС вірогідно пов'язано з гострим токсичним зовнішнім впливом. Це положення підтверджується подовженням часу засинання і скороченням часу медикаментозного сну, тобто має місце активація детоксикаційно функці печінки, яка обумовлена, імовірно, також зовнішнім впливом. Дані про ці зміни наведені у таблиці 2.

Проведене дослідження показників стану периферійно крові і імунно відповіді у піддослідних щурів, що одержували воду оз. Катлабух, наведено в таблиці 3.

Таблиця 2. Зміни показників тіопенталово проби у здорових щурів під впливом води оз. Катлабух

\begin{tabular}{|l|c|c|c|}
\hline \multicolumn{1}{|c|}{ Показники } & $\begin{array}{c}\text { Контроль } \\
\left(\mathrm{M}_{1} \pm \mathrm{m}_{1}\right)\end{array}$ & $\begin{array}{c}\text { Дослід } \\
\left(\mathrm{M}_{2} \pm \mathrm{m}_{2}\right)\end{array}$ & $\mathrm{p}$ \\
\hline Час засинання, хв & $2,33 \pm 0,11$ & $3,06 \pm 0,01$ & $<0,05$ \\
\hline Тривалість медикаментозного сну, хв & $80,17 \pm 0,10$ & $58,12 \pm 0,18$ & $<0,001$ \\
\hline
\end{tabular}

Таблиця 3. Периферійна кров і імунна відповідь у щурів, що одержували воду оз. Катлабух

\begin{tabular}{|c|c|c|c|}
\hline Показник & Контроль & Дослід & $\mathrm{p}$ \\
\hline 1 & 2 & 3 & 4 \\
\hline Еритроцити, $10^{12} /$ дм $^{3}$ & $3,91 \pm 0,09$ & $4,18 \pm 0,12$ & $>0,5$ \\
\hline Гемоглобін, Г/дм & $135,78 \pm 2,60$ & $144,60 \pm 4,12$ & $>0,5$ \\
\hline Кольоровий показник, ум. од. & $1,05 \pm 0,03$ & $1,04 \pm 0,01$ & $>0,5$ \\
\hline ШОЕ, мм/год & $1,30 \pm 0,11$ & $1,15 \pm 0,08$ & $>0,5$ \\
\hline
\end{tabular}




\begin{tabular}{|c|c|c|c|}
\hline 1 & 2 & 3 & 4 \\
\hline Лейкоцити, $10^{9} /$ дм $^{3}$ & $6,50 \pm 0,56$ & $6,21 \pm 0,47$ & $>0,5$ \\
\hline Лімфоцити, \% & $77,7 \pm 1,11$ & $78,00 \pm 1,56$ & $>0,5$ \\
\hline Нейтрофіли, \% & $15,7 \pm 0,92$ & $15,3 \pm 1,4$ & $>0,5$ \\
\hline Ацидофіли, \% & $3,30 \pm 0,35$ & $3,60 \pm 0,60$ & $>0,5$ \\
\hline Моноцити, \% & $3,30 \pm 0,20$ & $3,20 \pm 0,25$ & $>0,5$ \\
\hline ЦІК, г/дм ${ }^{3}$ & $4,95 \pm 0,14$ & $5,19 \pm 0,14$ & $>0,5$ \\
\hline ГА, ум. од. & $5,40 \pm 0,90$ & $11,60 \pm 2,76$ & $<0,005$ \\
\hline Антитіла печінки, ум. од. & 0 & $3,0 \pm 1,53$ & $>0,5$ \\
\hline Антитіла мозку, ум. од. & 0 & 0 & - \\
\hline
\end{tabular}

Як свідчать дані таблиці 3, кількість еритроцитів у піддослідних тварин вірогідно збільшується, як і кількість гемоглобіну. Оскільки кольоровий показник залишається в межах норми, можна стверджувати, що в організмі щурів посилюється транспортна функція крові, а це звичайно буває при необхідності компенсувати функціональну гіпоксію, обумовлену попаданням в організм токсинів, які діють на процеси енергоутворення. Свідченням того, що в складі води не присутні сполуки, що впливають на білковий синтез та сенсибілізацію організму, є збереження на рівні контролю показників білкового складу плазми і стану клітинного компонента імунно відповіді. Серед показників стану гуморального компонента імунно відповіді відмічається зростання вмісту гетерогенних антитіл і поява достатньо кількості антитіл до печінки. Інші показники імунно відповіді залишаються в нормі.

Результати досліджень функці нирок при споживанні щурами води оз. Катлабух показують, що видільна функція нирок, а також функція сечоутворення не змінюються, про що свідчить збереження практично незмінним обсягу добового діурезу, швидкості фільтраці і реабсорбці . Деяке зниження pH сечі може бути пов'язане зі зміною складу виведених метаболітів. Що стосується іонообмінно функці нирок, то має місце затримка іонів натрію і калію в організмі щурів, що можливо пов'язано зі зміною енергообміну в клітинах організму щурів під впливом води оз. Катлабух.

Висновки. 1. Результати фізико-хімічних та санітарно-хімічних досліджень води оз. Катлабух свідчать про відповідність вимогам ДСТУ 4808:2007 до джерел 2-4 класу якості.

\section{ЛІТЕРАТУРА}

1. Мокиенко А. В. Питьевая вода и водно-обусловленные инфекции (сообщение седьмое). Цианобактерии и цианотоксины / А. В. Мокиенко, Н. Ф. Петренко // Вода і водоочисні технологі . - 2008, - № 3 (27). - С. 22-31.

2. Вода и водно-обусловленные инфекции / А. В. Мокиенко, А. И. Гоженко, Н. Ф. Петренко, А. Н. По-
2. У воді оз. Катлабух виявлено 2 види ціанобактерій Merismopedia minima та Spirulina laxissima, які викликають «цвітіння» води.

3. Встановлено, що вживання здоровими щурами як питно води оз. Катлабух супроводжується наступними ефектами: підвищенням активності ЦНС; компенсаторною функціональною гіпоксією, обумовленою, вірогідно, впливом токсинів, які діють на процеси енергоутворення; зростанням вмісту гетерогенних антитіл і появою достатньо кількості антитіл до печінки, тобто аутоімуних реакщій, що може бути основою для дистрофічних і деструктивних процесів; зниженням рН сечі, затримки іонів натрію і калію, що можливо пов'язано зі зміною енергообміну в клітинах організму щурів.

4. Зважаючи на відсутність гігієнічно значимих концентрацій антропогенних забруднювачів (за винятком перевищення концентраці ванадію для джерел 1 класу якості), можна з певною вірогідністю вважати, що виявлені біологічні ефекти 6 наслідком ді ціанотоксинів, які продукують виявлені ціанобактері . Враховуючи суттєве перевищення мінералізаці та концентрацій основних катіонів та анінів води, високі рівні загального органічного вуглецю, а також органічну природу ціанотоксинів (олігопептиди, алкало ди, ліпополісахариди), цілком вірогідно, що має місце формування токсичних органомінеральних комплексів, дія яких досі не досліджувалась.

Перспективи подальших досліджень. Слід вважати за необхідне розширення та продовження досліджень ціанобактерій у контекстах x виявлення у воді, ідентифікаці ціанотоксинів, впливу цих ксенобіотиків на стан теплокровних тварин та людини.

номаренко. - Одесса : Лерадрук. - 2008, - Т. 1. - 412 с.

3. Ковальчук Л. Й. Гігієнічна оцінка евтрофікаці поверхневих водойм Укра нського Придунав'я / Л. Й. Ковальчук, А. В. Мокієнко // Актуальні проблеми сучасно медицини: Вісник Укра нсько медично стоматологічно академі . - 2014. - Т. 14, Випуск 4 (48). - С. 73-78. 
4. Ковальчук Л. И. Гигиеническая оценка цианобактерий озер Украинского Придунавья / Л. И. Ковальчук, А. В. Мокиенко, Д. А. Нестерова // Досягнення біологі та медицини. - 2014. - № 2. - С. 10-14.

5. Посібник з методів досліджень природних та преформованих лікувальних засобів: мінеральні природні лікувально-столові та лікувальні води, напо на х основі; штучно-мінералізовані води; пелоди, розсоли, глини, воски та препарати на хній основі / Н. О. Алексєєнко, О. С. Павлова, Б. А. Насібуллін, А. С. Ручкина. - Ч. 3. Одеса : ЮНЕСКО-СОЦІО, 2002. - $114 \mathrm{c}$.

6. Радченко И. Г. Практическое руководство по сбору и анализу проб морского фитопланктона. Учебно-методическое пособие для студентов биологических специальностей университетов / И. Г. Радченко, В. И. Капков, В. Д. Федоров / - М. : Мордвинцев, 2010. - 60 с.

7. Наказ Міністерства освіти і науки, молоді та спорту Укра ни від 01.03.2012 р. № 249. - Офіційний вісник Укра ни від 06.04.2012. - № 24. - С. 82; стаття 942, код акта 60909/2012.

8. Directive 2010/63/ EU of the European Parliament and of the Council of 22 September 2010 on the protection of animals used for scientific purposes (Text with EEA relevance) // Official Journal L 276, 20.10.2010. - P. 0033 0079 .

9. Методичні рекомендаці з методів досліджень біологічно ді природних лікувальних засобів та преформованих засобів: мінеральні природні лікувальностолові та лікувальні води, напо на х основі; штучномінералізовані води; пело ди, розсоли, глини, воски та препарати на хній основі: Затверджено наказом МОЗ Укра ни від 28.09.2009p. за № 692. Ки в, 2009.$117 \mathrm{c}$.

10. ГланцС. Медико-биологическая статистика : пер. с англ. Ю. А. Данилова ; под ред. Н. Е. Бузикашвили и Д. В. Самолова. - М. : Практика, 1999. - 459 с.

11. Джерела централізованого питного водопостачання. Гігієнічні та екологічні вимоги щодо якості води і правила вибирання : ДСТУ 4808-2007 : К. : Держспоживстандарт Укра ни, 2007. - [Чинний від 01.01.2009]. $36 \mathrm{c.}$

12. Санитарные правила и нормы охраны поверхностных вод от загрязнения. СанПиН № $4630-88 .-$ М. : M3 CCCP, 1988. -69 c.

\title{
COMPREHENSIVE ASSESSMENT OF FUNCTIONAL CHANGES IN HEALTHY RATS THAT CONSUMED AS DRINKING WATER OF KATLABUKH LAKE
}

\author{
CL. I. Kovalchuck', A. V. Mokiyenko², B. A. Nasibullin ${ }^{3}$, L. B. Solodova ${ }^{3}$, \\ S. G. Guzha ${ }^{3}$, A.Ya. Oleshko ${ }^{3}$, E. I. Baholdina ${ }^{3}$ \\ Odesa National Medical University'; \\ State Enterprise Ukrainian Research Institute for Medicine of Transport \\ of the Ministry of Health Care of Ukraine ${ }^{2}$ \\ Public Institution «Ukrainian Re search Institute of Medical Rehabilitation and Balneology \\ of the Ministry of Health Care of Ukraine ${ }^{3}$
}

SUMMARY. The work is devoted to a comprehensive assessment of functional changes in healthy rats organism who consumed as drinking water of the Katlabukh lake. The results of physico-chemical and sanitary-chemical investigations of the Katlabukh lake water indicate its compliance with the requirements of Ukrainian state standard (DSTU) 4808: 2007 to the sources of 24 class quality. 2 species of cyanobacteria Merismopedia minima and Spirulina laxissima, which cause water bloom have been found. It was found that the use by healthy rats the water of Katlabukh lake was accompanied by the following effects: increased activity of the central nervous system; compensatory functional hypoxia; increase and appearance of heterogeneous antibodies and antibodies to the liver, i.e. autoimmune reactions; urine $\mathrm{pH}$ reduction, delay sodium and potassium ions. It is suggested that the biological effects identified are a consequence of the action of eeither cyanotoxins or any toxic organomineral complexes. The expediency of expansion and continued research of cyanobacteria in the contexts of their detection in water, the identification of cyanotoxins, the impact of these xenobiotics on the state of warm-blooded animals and humans substantuated. KEY WORDS: water, Katlabukh lake, chemical composition, anthropogenic pollutants, cyanobacteria, biological effects, rats. 